Review

\title{
A policy review of synergies and trade-offs in South African climate change mitigation and air pollution control strategies
}

\author{
Carmen Klausbruckner ${ }^{\text {a,* }}$, Harold Annegarn ${ }^{\mathrm{b}}$, Lucas R.F. Henneman ${ }^{\mathrm{c}}$, Peter Rafaj ${ }^{\mathrm{d}}$ \\ a Johannes Kepler University, Linz, Austria \\ ${ }^{\mathrm{b}}$ Energy Institute, Cape Peninsula University of Technology, Cape Town, South Africa \\ ${ }^{\mathrm{c}}$ Georgia Institute of Technology, Atlanta, GA, USA \\ ${ }^{\mathrm{d}}$ International Institute for Applied Systems Analysis, Laxenburg, Austria
}

\section{A R T I C L E I N F O}

\section{Article history:}

Received 23 July 2015

Received in revised form 12 November 2015

Accepted 1 December 2015

\section{Keywords:}

Climate change

Air pollution

Contradicting policies

Co-benefits

GAINS

South Africa

\begin{abstract}
A B S T R A C T
Climate change mitigation and air quality management are mostly addressed separately in South African legal acts and policies. This approach is not always coherent, especially in the context of other serious issues South Africa is facing, such as poverty alleviation. Policies implemented to mitigate climate change might increase negative health affects due to unanticipated outcomes (e.g. increased local air pollution), and these indirect consequences must therefore be taken into account when devising mitigation strategies. However, greenhouse gas mitigation policies can also have co-benefits and positive impacts on local air pollution. An evidence-based approach that takes into account greenhouse gas emissions, ambient air pollutants, economic factors (affordability, cost optimisation), social factors (poverty alleviations, public health benefits), and political acceptability is needed tackle these challenges. A proposal is made that use of an integrated climate/air pollution techno-economic optimising model, such as the Greenhouse Gas and Air Pollution Synergies (GAINS) model, may provide a rational decision support tool to guide policy makers into effective strategies for combined Climate Change and Air Quality mitigation measures.
\end{abstract}

() 2015 Elsevier Ltd. All rights reserved.

\section{Introduction}

South Africa is an emerging country and the second largest economy in Africa. In terms of energy, a key to South Africa's past economic success was low energy prices that attracted and supported energy intensive industries. In turn, this has led to high emissions per capita of greenhouse gases (GHG) from the predominantly coal-fired power industry. Over the past decade, however, the relative abundance of low-cost electricity has changed-in the past years there have been electricity generation shortfalls and forced blackouts, and electricity prices have risen at rates well above inflation.

The power sector in South Africa is dominated by the state owned company Eskom, which produces 95\% of the country's electricity ${ }^{1}$. The main resource used for power generation is $\mathrm{coal}^{2}$. South Africa is the largest $\mathrm{CO}_{2}$ emitter in Africa. In 2004,

\footnotetext{
* Corresponding author. Tel.: +43 69919135501.

E-mail address: c.klausbruckner@gmx.at (C. Klausbruckner).

1 http://www.eskom.co.za/OurCompany/CompanyInformation/Pages/ Company_Information.aspx (accessed 10.11.2015).

${ }^{2}$ For more information on the South African coal sector see (Eberhard, 2011).
}

South Africa emitted $440 \mathrm{Mt} \mathrm{CO}_{2}$ eq., which was around $1 \%$ of the global emissions. The share increased to almost $1.4 \%$ in $2010^{3}$, giving South Africa the status of one of the world's most carbon intensive economies. At the UNFCCC Conference of the Parties in Copenhagen (COP 15 ) in 2009, the country made a political commitment to reduce significantly its GHG emission (UNFCCC, 2011).

Local air pollution is another pressing issue due to its negative health impacts (Norman et al., 2007; Matinga et al., 2014; Shirinde et al., 2014). Electricity generation, industrial processes, domestic energy use and vehicular exhaust emissions are the main contributors to air pollution in South Africa (Scorgie et al., 2004).

Environmental issues in South Africa are frequently connected with the question of environmental justice, since these issues are linked to the question of poverty. Local air pollution disproportionally affects poorer (historically disadvantaged black) communities that are located close to industries (Dugard and Alcaro, 2013). Use of inferior quality fuel burning appliances expose these communities to concentrations of smoke and carbon monoxide

\footnotetext{
${ }^{3}$ See http://data.worldbank.org/indicator/EN.ATM.CO2E.KT/countries (accessed 10.11.2015).
} 
that cause adverse health effects (Shirinde et al., 2014). Furthermore, poorer households are likely to be more vulnerable to adverse effects of climate change, a consideration that has been taken into account in South African climate change adaptation strategies (DEA, 2013).

The purpose of this paper is to conduct a policy and legal analysis of South African climate and air pollution control policy strategies. The second section gives a perspective on South Africa's overall policy orientation, and explores issues surrounding air pollution and climate change. The policy frameworks in the fields of air quality and climate change are outlined in the third section. The discussion includes an overview of the legal framework, with special attention paid to how the different policies articulate with each other. Additional details (especially on international commitments, constitutional rights, legislation, and regulations) can be found in the Supplementary Material. The fourth section explores inconsistencies and contradictions between air quality and climate change policies, and implementation strategies within the current legal and policy framework. In the final section, a resolution of these inherent contradictions is offered through the implementation of an evidence-based, integrated approach, together with criteria for employing this approach that is applicable also for other developing countries facing similar problems. This approach has been adopted successfully for integrated assessments in Europe and in numerous developing countries in Asia (Purohit et al., 2010, 2013; Chen et al., 2015).

\section{South Africa's position on mitigating climate change and the problem of local air pollution}

\subsection{Climate change}

Climate change is a global issue that also affects South Africa. In 2013 South Africa was ranked 27th in the Global Climate Risk Index (Kreft et al., 2014). South Africa has ratified the major treaties on climate change: the 1992 UN Convention on Climate Change in 1997, and the 1997 Kyoto Protocol in 2002. Obligations regarding these treaties are determined according to the principle of common but differentiated responsibility. South Africa is listed as a developing country in Annex I of the Kyoto Protocol, and therefore has no obligations to reduce GHG emissions. Nevertheless, at the UNFCCC Conference of the Parties in Copenhagen in 2009 (COP 15), South Africa committed itself to reduce its GHG emissions $34 \%$ by 2020 and $42 \%$ by 2025 in comparison with the "Business as Usual" trajectory ${ }^{4}$ (UNFCCC, 2011), subject to conditions of technical and financial support from the developed countries.

\subsection{Air pollution}

Ambient - especially indoor - air pollution, are major public health issues. Local air pollution increases the risk of acute respiratory tract infections and pneumonia, especially in children of low-income communities-in 2012 the pneumonia incidence rate for children under five years was 66.8 out of $1000^{5}$, and an increased risk of wheezing for children due to outdoor and indoor air pollution was found in the Child Highveld Priority Area Study (Shirinde et al., 2014).

Domestic fuel use (mainly of coal, wood and kerosene) is a source of indoor and local air pollution. The problem occurs in South Africa particularly in informal settlements near major cities, but also in rural areas. Especially in winter, ambient particulate

\footnotetext{
${ }^{4}$ http://www.climateaction.org.za/cop17-cmp7/

sa-government-position-on-climate-change (6.7.2015)).

5 http://indicators.hst.org.za/healthstats/209/data (accessed 10.11.2015).
}

concentrations can reach dangerously high levels in places such as Soweto, South Africa's largest township (Scorgie et al., 2004).

The use of electricity for cooking is increasing from 58\% in 2002 to 78\% in 2013 (General Household Survey, 2014). However, in some provinces (Limpopo, KwaZulu-Natal, Mpumalanga, Eastern Cape) solid fuels remain an important source of energy for cooking. Even if households are electrified, other fuels are still used extensively for cooking, for economic reasons ${ }^{6}$ (Matinga et al., 2014). Apart from air pollution, the use of solid fuels increases the likelihood of burn injuries and fire accidents (Kimemia et al., 2014).

\section{Existing policies}

Climate change is a global concern with GHG reductions discussed on the international level, whereas air pollution is a national concern that is addressed primarily on national, provincial, and local levels. However, measures to reduce GHG emissions have to be taken on the national and local levels. To understand the dynamics between climate change and air pollution, it is necessary to examine the policy papers and legal measures across all these areas. Legal measures in South Africa include the National Environmental Management: Air Quality Act (NEM:AQA) and its instruments (Ambient Air Quality Standards (AAQS), Priority Areas, Minimum Emission Standards (MES), Pollution Prevention Plans, Emission Licences), and are outlined in the Supplementary Material.

Before analysing specific measures in certain policy areas, the overall direction of South African policy development has to be outlined to show the national priorities. As a starting point, an overview is given of the recently developed National Development Plan (NDP), which is intended as the overarching policy framework for all aspects of national development over the next decade and beyond (National Planning Commission, 2013).

The National Development Plan was prepared by the presidential appointed National Planning Commission. The aim of the NDP is to provide implementable steps towards the sustained development of South Africa. It comprises all sectors (inter alia employment, poverty reduction, growth, health, infrastructure, etc.), identifies challenges, and gives a comprehensive outlook of the future challenges of the country with the time horizon to 2030. In order to implement the National Development Plan, the MediumTerm Strategic Framework (MTSF) 2014-2019 was published (The Presidency, 2014). The NDP stresses that the highest priority should be given to increase employment and improve the quality of education. The document focuses on economic development and takes into consideration the need for electricity (sufficient supply) for economic growth. GHG mitigation and health protection are detailed as challenges in this context. A major emphasis of the NDP is the need for investment in infrastructure for public transport, exploitation of coal resources, distribution and use of natural gas, and installation of $20000 \mathrm{MW}$ renewable electricity by 2030 (compared to $1000 \mathrm{MW}$ in 2009) (Edkins et al., 2010).

According to the National Development Plan, 95\% of the South African population should have access to electricity by 2030. An additional $29000 \mathrm{MW}$ of electric capacity is needed by 2030, which means new installed capacity of about $40000 \mathrm{MW}$ (20000 MW renewables) due to the decommissioning of some older coal-fired power stations. The National Development Plan also addresses the need for affordable electricity for the poor. However, the necessity to increase electricity prices to finance Eskom is mentioned. The plan acknowledges the problem of energy poverty and the need for safe domestic combustion. Concrete measures for achieving these goals are not specified in the plan.

\footnotetext{
${ }^{6}$ See http://soer.deat.gov.za/42.html (accessed 10.11.2015).
} 
The NDP refers to the Climate Change Response White Paper (South African Government, 2011), which is discussed in more detail below. It is mentioned in the plan that the introduction of carbon taxes has to be handled carefully, especially in context of rising electricity prices. The White Paper proposes interventions to avoid negative effects on household energy poverty. Problems of air pollution and energy poverty are addressed, but air pollution is not specifically contemplated as a major health concern. Indoor air pollution and local air pollution are not mentioned in the White Paper under the section on health, but they are discussed in other high-level documents, such as the National Climate Change and Health Adaptation Plan (DEA, 2013).

\section{Climate change mitigation in South Africa}

Several reports, policy papers and, increasingly, legislative instruments deal with climate change. The focus is on the management of inevitable impacts due to climate change and adaption and on the reduction of GHG emissions in order to contribute to global efforts to mitigate GHG. Potential mitigations strategies include energy efficiency, the use of clean coal technologies, a switch to renewables (especially solar energy, see Pegels, 2010; Winkler, 2005; Winkler et al., 2009) and/or nuclear power. Furthermore, power generation from waste incineration and the use of biofuels, as well as the increased use of hydropower (e.g. Grand Inga Dam Project; see IEA, 2014) are mentioned in South Africa's mitigation strategies. Legal options include regulations such as emissions standards in the transport sector, the industrial sector, or the power sector (see further in the Supplementary Material). Enforcement is seen as the major problem for the success of these instruments. Other options are market interventions, such as carbon taxes that aim to internalise external costs induced by climate-related damages or the introduction of carbon budgeting (Winkler and Marquard, 2012; South African Government, 2011).

The most comprehensive work on mitigation strategies was the Long Term Mitigation Scenarios (LTMS) process, mandated by the cabinet, which took place from 2005 to $2008^{7}$. The aim of the project was to examine the possible long-term strategies whereby South Africa could contribute to the mitigation of climate change. The "Required by Science" scenario is driven by a climate target, with a goal for South Africa to reduce GHG emissions by the percentage that is globally needed to archive the $2{ }^{\circ} \mathrm{C}$ goal (a $30-$ $40 \%$ reduction in the year 2050 compared to the 2003 levels) (Scenario building Team, 2007).

Based on the outcomes of the LTMS, the Department of Environmental Affairs (DEA) in 2011 defined the Peak, Plateau and Decline (PPD) emission reduction trajectory as South Africa's contribution to the global $2{ }^{\circ} \mathrm{C}$ goal (Fig. 1) (DEA, 2011, 2014):

- South Africa's emissions to peak in the period 2020 to 2025 (within the range of $398 \mathrm{Mt}$ and $583 \mathrm{Mt} \mathrm{CO}_{2}$ eq. by 2020 and $614 \mathrm{Mt} \mathrm{CO}_{2}$ eq. by 2025)

- plateau for 10 years (398 to $615 \mathrm{Mt} \mathrm{CO}_{2}$ eq.)

- decline of emissions from 2036 onwards (2050: 212 to $428 \mathrm{Mt}$ $\mathrm{CO}_{2}$ eq.).

The most important policy paper on climate change mitigation, the National Climate Change Response White Paper (published in 2011), refers to this goal and mentions lower carbon emissions in

\footnotetext{
${ }^{7}$ It was conducted by the Department of Environmental Affairs and Tourism and undertaken by the Energy Research Centre (ERC) at University of Cape Town. See the documents under http://www.erc.uct.ac.za/Research/publications/ 07Scenario_team-LTMS_Scenarios.pdf (accessed 10.11.2015).
}

electricity generation, and energy efficiency and interventions in the transport sector as the midterm strategies with the biggest potential.

Measures that have already been taken include the introduction in September 2010 of an environmental levy on new vehicle purchases (R75 per gram of $\mathrm{CO}_{2}$ emissions per kilometre, over a threshold of $120 \mathrm{~g} / \mathrm{km}$ ). This levy adds from 2 to $4 \%$ to the total price of a new car. A levy on electricity $(2.0 \mathrm{c} / \mathrm{kW} \mathrm{h})$ produced from non-renewable sources was introduced in 2009 and increased to $2.5 \mathrm{c} / \mathrm{kWh}$ in 2011. Energy efficiency measures were introduced in the building sector in 2011; the National Building Regulations and Building Standards (SANS 10,400) incorporate minimum insulation requirements, solar heating systems, and efficient air conditioning and ventilation systems, and introduced standards for energy efficiency labelling (SANS 941) for domestic appliances. Measures to promote the use of renewables include the Renewable Energy Feed-In Tariff (REFIT) programme that was launched by the National Energy Regulator of South Africa (NERSA) in 2009. The feed-in tariff system was declared as inconsistent with current legislation and a bidding process was introduced in 2011 (the Renewable Energy Independent Power Producer Procurement program-REIPPP). (Msimanga and Sebitosi, 2014) Increasingly GHG emissions are starting to be targeted in air quality legislation, where, for example, "significant emitters of greenhouse gas" will have to incorporate GHG mitigation measures in their Air Pollution Prevention Plans. (See further in the Supplementary Material.)

One measure to lower carbon emissions in South Africa are carbon taxes, which were scheduled for implementation in 2015, but have been postponed to 2016. Carbon taxes are seen as more appropriate for South Africa than a cap-and-trade (emissions trading) system (National Treasury, 2013). Taxes are most likely to be accompanied by the possibility for firms to purchase offsets to reduce their carbon tax liability (National Treasury, 2014). According to the Carbon Offsets Paper (2014), a carbon offsets is defined as a "measurable avoidance, reduction or sequestration of carbon dioxide $\left(\mathrm{CO}_{2}\right)$ or other GHG emissions". Measures against other air pollutants are not included as possible offset candidates (National Treasury, 2014).

The principles of South Africa's climate change response include the common, but differentiated, responsibilities and respective capabilities, equity, and uplifting of the poor and vulnerable, which indicates that responses to climate change have to be in line with the broad aims of poverty alleviation (South African Government, 2011). The LTMS report mentions possible negative effects for poorer households, and effects on air pollution are partially considered. It discuses both the disproportionate impact of climate change on poorer households and considers climate change effects on future ambient air pollution levels (Energy Research Centre, 2007). Moreover, the report addresses the positive impact on local air quality that may be associated with the increased use of electric vehicles (Hughes et al., 2007).

Likewise, the Climate Change Response White Paper acknowledges that other factors, such as socio-economic development indicators, international competitiveness, the costs to poor households, and challenges to mitigate poverty have to be taken into account, and includes sections that discuss the relationship between climate change and local air quality. The report warns of an anticipated increase of stagnant air episodes due to climate change, which can lead to episodes of severe air pollution in cities. However, there is no link to an increased use of solid fuels in the domestic sector. This document states, regarding the reduction of ambient particulate matter, ozone and sulphur dioxide, that "use of legislative and other measures that also have the co-benefit of reducing GHG emissions will be prioritised" (point 5.4.1.). Also mentioned are newly implemented air quality regulations that 
require reporting of GHG emission reductions in pollution prevention plans. In this context, it is also written that the "synergy between prevention measures to reduce conventional air pollutants and GHG mitigation will be used in a holistic approach to manage air quality." (point 10.6)

Greater-than-inflation rate increases in electricity prices are expected to continue if climate change mitigation policies are implemented (Department of Energy, 2013), especially in the case of the introduction of a carbon tax (South African Government, 2011). Therefore, the implementation of carbon taxes will be supported by measures such as free basic electricity, which aim to provide poor and low-income households with electricity. The quantum of free electricity is currently (2015) set at $50 \mathrm{kWh}$ per month in most municipalities, an amount sufficient for basic lighting, entertainment and communication, but inadequate for cooking and heating, so this subsidy contributes little to mitigating local air quality issues from combustion of fuels (Madubansi and Shackleton, 2007; OECD, 2012). The introduction of carbon taxes is controversial. The effectiveness of a carbon tax is dependent on the level of taxation. It is seen, as a single measure - at the planned level of taxation as an insufficient incentive to users to initiate switches to other technologies. (Department of Energy, 2013)

The link between climate change and air pollution is recognised in South African policy documents on climate change. However, the consequences of climate change mitigation measures on air quality are frequently not addressed in an integrated way. It is only through the evolution and use of integrated assessment tools that such serious policy gaps or potential policy clashes may be avoided, and potential for co-benefits can be exploited. Measures that tackle local air pollution as well as GHG emissions should be prioritised. However, the statements are of general nature and do not include specific measures on how these tasks are to be implemented. The following section addresses the needs of such an integrated assessment.

\section{Policies to address local air pollution}

Strategies to minimise emissions due to the use of solid fuels in the domestic sector include the Integrated Household Clean Energy Strategy (ICHES) (Department of Minerals and Energy, 2004), the National Liquefied Petroleum Gas Strategy (Department of Energy, 2011), the Basa njengo Magogo campaign (a campaign to change user behaviour in the method of igniting solid fuel stoves) (Le Roux et al., 2009), and the Low-Smoke Fuel Programme that was initiated by the former Department of Minerals and Energy. National standards for stove design exist ${ }^{8}$, but are not effectively enforced.

Another measure that affects the availability of electricity and thus air emissions - is the electrification of households (Integrated National Electrification Programme-INEP). However, it should be taken into account that electrification does not necessarily lead to a switch from solid fuels to electricity (Matinga, 2010; Madubansi and Shackleton, 2006). Electricity prices might impact the use of electricity, but the topic is complex and the social dimension needs to be considered (Madubansi and Shackleton, 2007).

\section{Interim conclusions from the policy review}

South Africa has implemented diverse policies and laws to deal with air pollution and climate change. However, South Africa faces

\footnotetext{
${ }^{8}$ Compulsory specification for non-pressure paraffin stoves and heaters (2006). The Compulsory specification for coal-burning stoves and heaters for use in a dwelling (1982) has been withdrawn in 2014.
}

problems in implementing the prerequisites and requirements. Compliance and enforcement are considered weak (Craigie et al., 2009a). The fragmentation of governmental institutions is seen as one of the major challenges in the field of environmental protection in South Africa (Craigie et al., 2009b; Kotzé, 2009). The number of institutions involved is large, and creates problems for both the enforcement of existing laws and the consistency of different polices. Competencies in the field of environmental protection and climate change are split between different governmental bodies on the same level, and also between national, provincial and local government levels. The status of the Department of Environmental Affairs in the cabinet hierarchy is relatively low and certain environmental responsibilities are given to other more senior ministries with different priorities e.g. the Departments of Mineral Resources, or the Department of Energy (Leiman, 2014).

Preliminary results based on the previous findings can be summarised as follows:

a. In the context of international conventions, South Africa is considered a developing country and currently faces less pressure to contribute to pressing global environmental issues, but has committed itself to ambitious measures against global warming.

b. Climate Change is not a main priority in the overall national plan. Poverty eradication, job creation and education are the top priorities.

c. South African environmental law acknowledges that the eradication of poverty is a priority task of South African policy. As environmental degradation and global warming affect mostly those socio-economic sectors that have the least capacity to adapt, environmental protection and climate change mitigation are not contradictory, but have to be implemented in ways that address both issues simultaneously.

d. The constitutional right to a decent environment requires action to mitigate local air pollution. Climate change mitigation strategies therefore have to take into account their effects on local (indoor) air pollution.

e. South Africa's policy papers on climate change mitigation indicate that South Africa expects developed countries to contribute financially to the national reduction of GHG.

f. The most important policy paper on climate change mitigation, the Climate Change Response White Paper, is very broad and includes various topics. Strategic priorities are set, but concrete measures are not formulated. The link between ambient air pollution and GHG emissions is addressed, but the document lacks measures and goals in this context. Measures to mitigate local air pollution are not expressly stipulated.

g. Measures to lower local air pollution levels due to the use of solid fuels are not linked with climate change policies.

h. The introduction of carbon taxes is seen as an appropriate measure to induce behavioural change towards reducing carbon emissions, but scepticism exists as to whether the proposed levels will have any effect on changing fuel choices, and by increasing electricity prices, unintentionally drive users to return to use of locally polluting solid fuel use.

i. The existence of coherent legislation and policies does not always guarantee the application, as enforcement is weak in South Africa and institutional capacity is limited.

\section{Contradictions}

Up until 2004, climate change and air pollution were two topics that were dealt with separately in South African policy. The link between climate change and air pollution was first emphasised in 
The desired South African climate change mitigation outcome - the "Peak, Plateau and Decline" (PPD) greenhouse gas emission trajectory

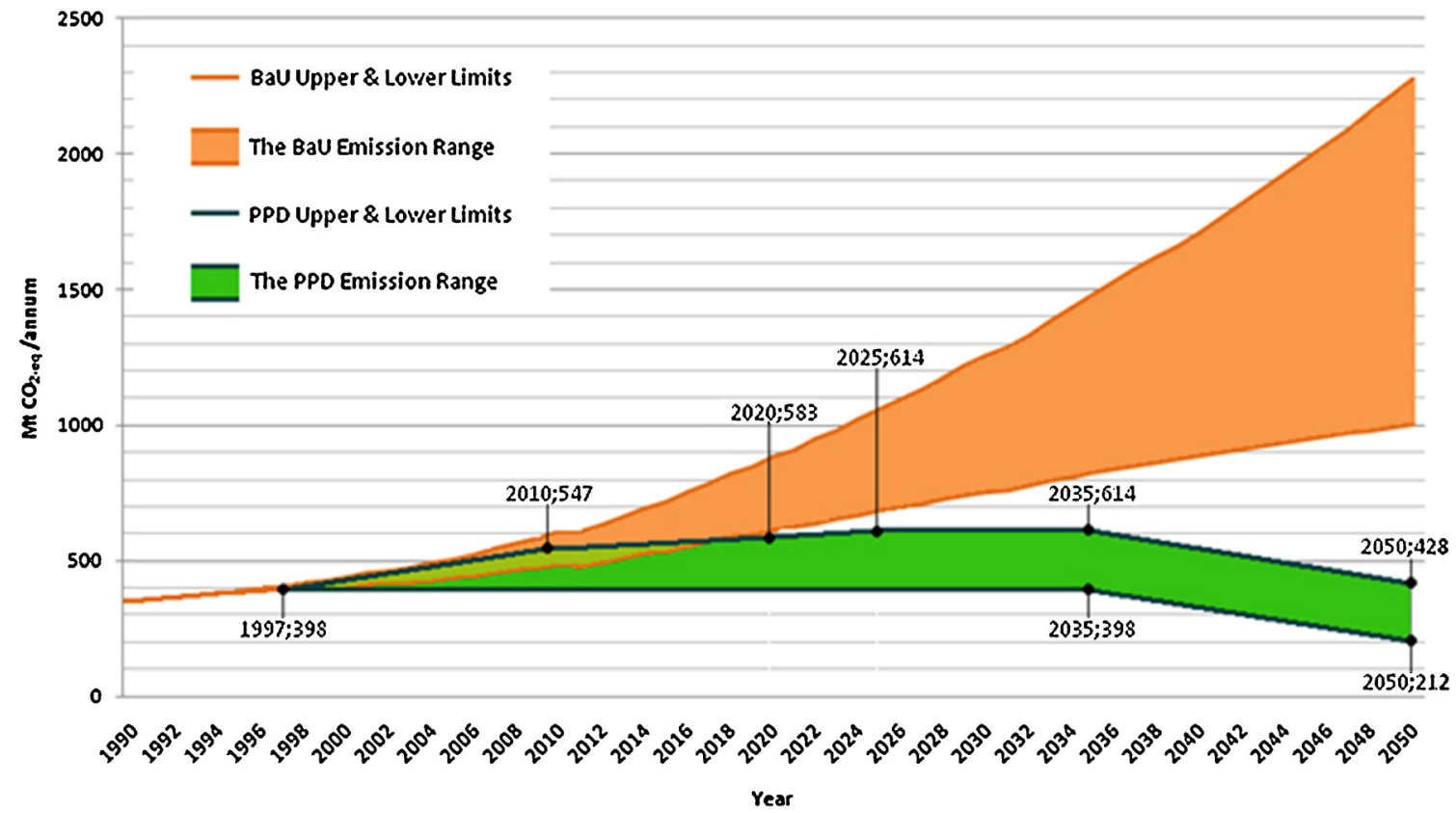

Fig. 1. The "Peak, Plateau and Decline" greenhouse gas emissions trajectory ${ }^{101}$.

official policy documents in the Climate Change Response Strategy $(2004)^{9}$. An information handling system was introduced as a first effort to incorporate GHG emissions in air quality legislation. In recent years, laws and policy papers in the field of air pollution and climate change refer to each other. However, the measures taken in the field of climate change and air pollution are still not entirely coherent.

Fig. 2 shows the interrelations between air quality legislation and policies and climate change mitigation policies. It shows that links between climate change policies and air quality management exist but local air pollution is more related with poverty alleviation and not directly addressed in climate mitigation policies.

The focus of the NDP is social questions, including access to electricity (Fig. 2). Climate change is targeted under the NDP, however, linkages between climate change and other issues such as poverty eradication or air pollution or are not addressed. By putting priority on heath related issues, an indirect link to indoor and local air pollution can be drawn (grey arrow). The White Paper targets air quality, but not in a comprehensive way regarding the consequences of climate change mitigation measures on (especially indoor) air pollution. Linkages to climate change are recognised in certain air quality acts. Details on the air quality legislation can be found in the Supplementary material.

Many proposed air pollution and GHG mitigations strategies will most likely lead to higher energy prices, resulting in policy contradictions. The introduction of Minimum Emission Standards and the need for investments to comply with these standards is expected to result in above inflation increases in electricity prices. Likewise, the introduction of a carbon tax will lead to increased electricity prices. The policy contradictions of current policies arise from the probable negative effects of these price increases on local air pollution. Increased electricity prices will lead to a switch away from clean(er) fuels to less expensive and more polluting solid fuels for the poorer economic strata, certainly for cooking and heating (OECD, 2012), and resultant lowered quality of life. Indirect effects of increased household air pollution include adverse health effects and increased absenteeism, thereby increasing societal costs of medical care and reduced productivity. Increases in electricity prices for GHG mitigation reasons, would have a disproportionate impact on the lowest socio-economic communities, which in direct contradiction to the primary national policy aims.

The discussions concerning the planned introduction of a carbon tax are accompanied by attempts to lower the impacts on poorer households. One option mentioned is to redistribute income generated by carbon taxes in the form of welfare transfers. In this case, these transfers would be used to lower energy prices for low-income households, and a shift towards the domestic use of fossil fuels could be prevented. However, this is in contradiction to recent fiscal policy to simplify national tax codes and collection and also affects the cost of doing business in South Africa-again an unintended outcome in contradiction to the primary aims of (productive) job creation and poverty alleviation.

Local air pollution damages are considered in the White Paper (South African Government, 2011) as externalities of the energy sector. Health effects from fuel switching due to increasing prices in the domestic sector are not considered in the White Paper.

Tensions exist between investments in control of pollution (e.g. desulphurisation) and investment in alternative energy sources (renewables, clean fuels in the domestic sector, offsets in the form of passive energy building technologies, even in the statesubsidised housing sector) (Henneman et al., 2016). Given the advanced state of implementation of provisions of the Air Quality Act through enforcement of Minimum Emission Limits, implementation of control technologies on the largest emitters is foreseen. Other approaches, such as air quality offset schemes (and only within the same geographic areas) aimed at optimising net human exposure, may provide more benefits than the Minimum Emission Standards.

Air quality as a health concern due "to inhalation of high particulate matter $\left(\mathrm{PM}_{2.5}, \mathrm{PM}_{10}\right)$ levels from domestic coal combustion" seems to have low priority in comparison with other major public health issues such as HIV and tuberculosis (National Planning Commission, 2013). It has to be mentioned that tuberculosis, a major epidemic disease prevalent among the South 


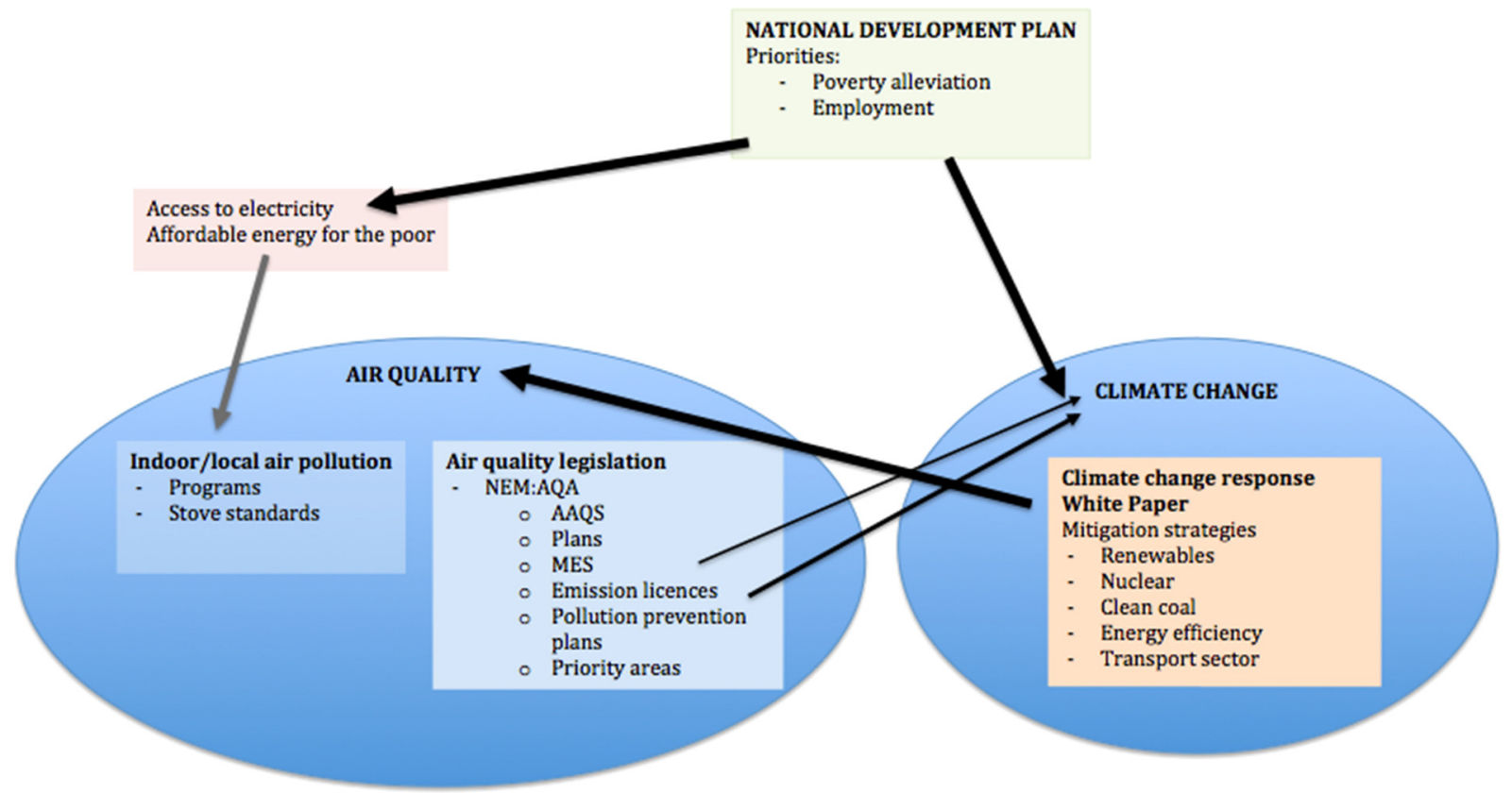

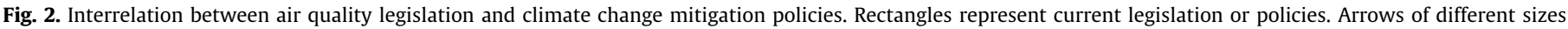
represent links to policies, and the strength of the link is shown by the thickness of the arrow.

African poor, is aggravated by local air pollution (Jassal et al., 2013). Therefore, air quality measures especially on the local level have to be considered within policies that target other health related issues.

Contradictions exist not only between climate change mitigation actions, but include other dimensions, such as access to electricity and poverty alleviation. Power generation in South Africa is connected with regional air pollution due to coal-fired power stations and therefore has significant health implications (Spalding-Fecher and Matibe, 2003). The need to electrify poorer households might lead to a higher electricity demand. The discussion includes an overview of the legal framework, with special attention paid to how the different policies interact with each other. However, a recent study shows that electrification of poor households for their basic needs does not significantly influence the overall GHG emissions (Tait and Winkler, 2012). They found that overall electricity consumption in the lowest income bands contributes less than $1 \%$ to the total national energy demand, and hence a shift in balance between energy carriers would change the overall GHG emissions by less than $1 \%$ (Tait and Winkler, 2012).

\section{Co-benefits}

GHG mitigation policies and air quality measures can have synergies and create co-benefits (Bollen et al., 2010; McCollum et al., 2013; Rao et al., 2013). There is a need to identify opportunities for co-benefits in air quality management and climate change mitigation (Naiker et al., 2012). Co-benefits might be the reduction of local air pollutants and associated control costs due to the controlling of GHG emissions. Policies that target GHG emissions usually lead also to a reduction of local air pollutants such as $\mathrm{SO}_{2}$ or $\mathrm{NO}_{x}$ (Rafaj et al., 2013). Any increase in investments in renewable energy sources will be accompanied with reduced

\footnotetext{
${ }^{10}$ http://www.climateaction.org.za/cop17-cmp7/ sa-government-position-on-climate-change (accessed 10.11.2015)

9 https://unfccc.int/files/meetings/seminar/application/pdf/ sem_sup3_south_africa.pdf (accessed 10.11.2015).
}

investments and operating costs in abatement technologies. Developing public transport or the usage of cleaner (electric powered) vehicles will lead to less emissions from transport, improved air quality, improved quality of health and reduced public health costs. Thambiran and Diab (2011a) found the reduction of travels with privately owned motor vehicles and the improving the efficiency of freight transport on roads to have great potential for co-benefits in Durban, South Africa. In assessing cobenefits it has to be taken into account that GHG mitigation can also have adverse effects (trade-offs) on air quality, because of, for example, increasing ozone exposure due to a higher share of fuelefficient diesel vehicles, or increasing exposure to particulates due to a larger use of wooden biomass fuels (Von Schneidemesser and Monks, 2013).

Fig. 3 shows the co-benefits of a scenario of GHG mitigation measures that would lead to South Africa's contribution to the global $2{ }^{\circ} \mathrm{C}$ goal as defined in the International Energy Agency's 2012 report (IEA, 2012). The proposed climate change mitigation measures would also lead to a decrease in air pollutants such as $\mathrm{SO}_{2}, \mathrm{NO}_{x}$ and to a lesser extent $\mathrm{PM}_{2,5}$ (Henneman et al., 2016).

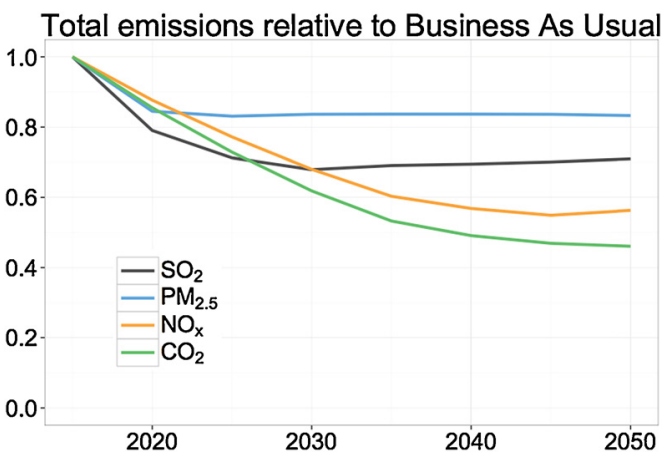

Fig. 3. Effects of South Africa's contribution to the Global $2{ }^{\circ} \mathrm{C}$ Scenario on the emissions of air pollutants (see Henneman et al., 2016) 
Benefits of climate change mitigation polices can also create benefits in other sectors. Climate change mitigation policies could create new jobs. Policy options such as the increase in renewables can create local employment (Walwyn and Brent, 2015). Small positive employment effects are expected from systematic programmes of energy efficiency implementation (Energy Research Centre, 2007).

\section{Resolution-Assessing consequences of climate change mitigation policies}

To resolve the contradictions inherent in South Africa's air quality legislation and climate change mitigation policies, an integration of policies is needed. Furthermore, the measures taken have to be in line with the national policy goals. Resolutions have to ensure no further disadvantage, direct or indirect, to lower socio-economic sectors. They have to be practical and acceptable to the voting public. Poverty alleviation, as a main target of South Africa's policy goals, is not only connected with the lack of money, but also with the lack of access to safe, affordable modern energy carriers and exposure to poor living conditions. The government has the responsibility to safeguard the health and wellbeing of its citizens. Bulk infrastructure has to be built in order to facilitate economic development, but the choices need to be made by optimising the overall societal benefits of investments, specifically taking into account the co-benefits of climate change and air quality strategies. These challenges need to be reconciled with South Africa's climate change aspirations, and commitments at the international level.

For example, as an alternative to major investments in retrofitting pollution abatement technologies to decades-old power plants that are approaching the end of their design life, the possibility of indirect offsets through investment in technologies for reduction of household air pollution (in the same geographical area) has been proposed as a major Department of Environmental Affairs policy intervention (DEA, 2015). An evaluation of such possibilities would need to be based on scientific evidence; a cost-benefits analysis, including externality factors, would be necessary.

Some trade-offs can be avoided if the policies are accompanied by specific measures. In the case of carbon taxes, the disadvantages for low-income households due to higher electricity prices could be offset by transfer payments, as suggested in the LTMS. It should be kept in mind that this kind of redistribution would involve administrative costs, and is connected with social problems of stigmatisation of the poor (Ruiters, 2008).

General measures that are necessary to enforce the prerequisites promulgated in Acts and policy papers have to be taken. The harmonisation of institutional action is necessary. This could be achieved, for instance, by placing the issues on the agendas of the appropriate inter-departmental ministerial clusters to strengthen cooperation between different departments. Any approaches taken have to be developed while keeping in mind that institutional capacity in South Africa is limited and any additional administrative burden has to be kept as low as possible.

Furthermore, singular measures are insufficient to address challenges associated with air pollution and climate change. Both issues need to be addressed simultaneously through integration of related policies, while avoiding unintended and unwanted consequences (Thambiran and Diab, 2011b; OECD, 2012). Climate change mitigation and air pollution policies need to have coherence with external factors dictated by the prevailing political, economic and social milieu in South Africa. The central policy pillars of the current government are employment creation, poverty alleviation and service delivery. Examples of such constraints are: implementing renewable energy technologies should require a large component of local content manufacture (job creation); proposed carbon taxes should not affect affordability of electricity to the lower economic strata (social equity); and major infrastructure interventions should be affordable and cost effective within the national infrastructure planning, supported by evidence-based argument. For example, a possible outcome may be indirect social and environmental offsets that create higher benefits for the public-calculated in disability adjusted life years (DALY). DALYs are used to estimate the burden of disease and take into account human wellbeing (Murray, 1994). The use of DALYs in recent years recognises the need to estimate the health effects of environmental pollutants in a nonmonetised way (Gao et al., 2015). However, limitations exist in countries such as South Africa, where data for incidence and prevalence of diseases are scarce. Hospital and clinical records in the public sector have not been well maintained in South Africa over the past twenty years. Good health data only exists for the upper income groups through private medical insurance schemes.

Tools that are capable of providing necessary information are models that take into account the different aspects in a common framework and fulfil the given criteria. One option is the Greenhouse Gas and Air pollution Interaction and Synergies (GAINS) Model that has already successfully been used as a policy support tool in Europe and Asia. (Amann et al., 2011) It is an integrated assessment model that has been developed by IIASA (International Institute for Applied Systems Analysis). The GAINS model links GHG and air pollution, and aims to support informed decision making that maximise synergies between different measures (co-benefits), and accounts for societal benefits/costs through calculating DALYs. GAINS can optimise on minimum costs, lowest air emissions, or lowest DALYs (health impacts). While the model does have limitations, the GAINS modelling framework has been proved to be able to comply with most of the criteria outlined above. Further details are provided in the following literature: Hordijk and Amann (2007), Rao et al. (2013), Reis et al. (2012).

South Africa currently is covered by the GAINS Global model. However, this generalised implementation is not as evolved as the European regional model. The Global model, for example, does not allow for quantification of impacts on health, crops or ecosystems in South Africa. To achieve the full functionality the model has to be complemented with the appropriate dispersion modelling tool (using the regional emission transfer coefficients and sourcereceptor matrix), which would compute concentration and deposition of polluting substances. Recently, a first co-benefit analysis for South Africa using the GAINS framework has been done by Henneman et al. (2016). A baseline scenario, control scenarios and activity scenarios were implemented to show the effects of different policy approaches to mitigate climate change and reduce air pollution and their costs. It is shown that climate change mitigation can induce synergies in reducing air pollutants at the same time (Fig. 3).

A full implementation of GAINS or a similar integrated decision support model in South Africa would assist South Africa in GHG and air quality policies and strategies. A full implementation of GAINS would provide considerable impetus to relax the current political and economic tensions in South Africa between a broad support for the need for positive steps to mitigate climatedamaging GHGs, and the inability to rationalise the cost of such measures in terms of near-term environmental and economic imperatives. The implementation of GAINS in South Africa could also be a starting point for an implementation in the whole southern African region, and provide knowledge for other developing regions. 


\section{Acknowledgements}

The paper was part of the work conducted in the Southern African-Young Scientists Summer Programme (SA-YSSP) 2014/15 that was organised by the International Institute for Applied Systems Analysis (IIASA), the National Research Fund (South Africa), the Department of Science and Technology, Republic of South Africa (South Africa) and the University of Free State, Bloemfontein, South Africa. The authors would like to thank the anonymous reviewers for their valuable comments and suggestions to improve the paper.

\section{Appendix A. Supplementary data}

Supplementary data associated with this article can be found, in the online version, at http://dx.doi.org/10.1016/j.envsci.2015.12. 001

\section{References}

Amann, M., Bertok, I., Borken-Kleefeld, J., Cofala, J., Heyes, C., Höglund-Isaksson, L., Klimont, Z., Nguyen, B., Posch, M., Rafaj, P., Sandler, R., Schöpp, W., Wagner, F., Winiwarter, W., 2011. Cost-effective control of air quality and greenhouse gases in Europe: modeling and policy applications. Environ. Model. Software 26, 1489-1501, http://dx.doi.org/10.1016/ j.envsoft.2011.07.012.

Bollen, J., Hers, S., van der Zwaan, B., 2010. An integrated assessment of climate change, air pollution, and energy security policy. Energy Policy 38, 4021-4030, http://dx.doi.org/10.1016/j.enpol.2010.03.026.

Chen, F., Yamashita, K., Kurokawa, J., Klimont, Z., 2015. Cost-benefit analysis of reducing premature mortality caused by exposure to ozone and PM2.5 in East Asia in 2020. Water Air Soil Pollut. 226, 1-17, http://dx.doi.org/10.1007/ s11270-015-2316-7.

Craigie, F., Snilman, P., Fourie, M., 2009a. Dissecting environmental compliance and enforcement. In: Peterson, A., Kotzé, L. (Eds.), Environmental Compliance and Enforcement in South Africa. Legal Perspectives, Cape Town.

Craigie, F., Snilman, P., Fourie, M., 2009b. Environmental compliance and enforcement institutions. In: Peterson, A., K.L., (Eds.), Environmental Compliance and Enforcement in South Africa. Legal Perspectives. Juta Law, Cape Town.

DEA, 2011. Defining South Africa's Desired Greenhouse Gas Mitigation Outcomes-Research, Concerns, Issues and Proposals. Department of Environmental Affairs, Pretoria, South Africa.

DEA, 2013. Long-term adaptation scenarios flagship research programme (LTAS) for South Africa. In: Climate Change Implications for Human Health in South AfricaDepartment of Environmental Affairs, Pretoria, South Africa.

DEA, 2014. South Africa's greenhouse gas (GHG) mitigation potential analysis. Department of Environmental Affairs, Pretoria, South Africa.

DEA, 2015. Air Quality Offset Guidelines. Department of Environmental Affairs, Pretoria, South Africa.

Department of Energy, 2011. Presentation to the Select Committee on Economic Development-Update on LPG Issues. 2 November 2011. Department of Energy, Pretoria, South Africa.

Department of Energy, 2013. Integrated Resource Plan for Electricity 2010-2030. Department of Energy, Pretoria, South Africa.

Department of Minerals and Energy, 2004. Integrated Household Clean Energy Strategy (ICHES). Department of Minerals and Energy, Pretoria, South Africa.

Dugard, J., Alcaro, A., 2013. Let's work together: environmental and socioeconomic rights in the courts. S. Afr. J. Hum. Rights 29, 14-31.

Edkins, M., Marquard, A., Winkler, H., 2010. South Africa's Renewable Energy Policy Roadmaps. Energy Research Centre, Cape Town, South Africa.

Eberhard, A., 2011. The Future of South African Coal: Market, Investment, and Policy Challenges. Stanford University.

Energy Research Centre, 2007. Long Term Mitigation Scenarios: Technical Appendix. Department of Environment Affairs and Tourism South Africa, Pretoria, South Africa.

Gao, T., Wang, X.C., Chen, R., Ngo, H.H., Guo, W., 2015. Disability adjusted life year (DALY): a useful tool for quantitative assessment of environmental pollution. Sci. Total Environ. 511, 268-287, doi:http://dx.doi.org/10.1016/ j.scitotenv.2014.11.048.

General Household Survey 2013, 2014. Statstics South Africa. General Household Survey, Pretoria, South Africa.

Henneman, L., Rafaj, P., Annegarn, H.J., Klausbruckner, C., 2016. Assessing emission levels and costs associated with climate and air pollution policies in South Africa. Energy Policy 89, 160-170, http://dx.doi.org/10.1016/ j.enpol.2015.11.026.

Hordijk, L., Amann, M., 2007. How science and policy combined to combat air pollution problems. Environ. Policy Law 4, 336-340.
Hughes, A., Haw, M., Winkler, H., Marquard, A., Merven, B., 2007. Energy Modeling: A Modeling Input into the Long Term Mitigation Scenarios Process. Energy Research Centre, Cape Town, South Africa.

IEA, 2012. Energy Technology Perspectives 2012. International Energy Agency, Paris, France.

IEA, 2014. Africa Energy Outlook-A Focus on Energy Prospects in Sub-Saharan Africa. International Energy Agency, Paris, France.

Jassal, M.S., Bakman, I., Jones, B., 2013. Correlation of ambient pollution levels and heavily-trafficked roadway proximity on the prevalence of smearpositive tuberculosis. Public Health 127, 268-274, http://dx.doi.org/10.1016/ j.puhe.2012.12.030.

Kimemia, D., Vermaak, C., Pachauri, S., Rhodes, B., 2014. Burns, scalds and poisonings from household energy use in South Africa: are the energy poor at greater risk? Energy Sustainable Dev. 18, 1-8, http://dx.doi.org/10.1016/ j.esd.2013.11.011.

Kotzé, L., 2009. Environmental Goverance. In: Paterson, A.R., Kotze, L. (Eds.) Environmental Compliance and Enforcement in South Africa: Legal Perspectives. JUTA, Cape Town, South Africa, pp. 103-125.

Kreft, S., Eckstein, D., Junghans, L., Kerestan, C., Hagen, U., 2014. Global Climate Risk Index 2015. Germanwatch e.V., Bonn, Germany.

Le Roux, L.J., Zunckel, M., McCormick, S., 2009. Reduction in air pollution using the "basa njengo magogo" method and the applicability to low-smoke fuels. J. Energy S. Afr. 20, 3-10.

Leiman, T., 2014. Environmental policy and the state in post-apartheid South Africa. In: Bhorat, H., Hirsch, A., Kanbur, R., Ncube, M. (Eds.), The Oxford Companion to the Economics of South Africa. Oxford University Press, Oxford, United Kingdom, pp. 401-409.

Madubansi, M., Shackleton, C.M., 2006. Changing energy profiles and consumption patterns following electrification in five rural villages. S. Afr. Energy Policy 34, 4081-4092, http://dx.doi.org/10.1016/j.enpol.2005.10.011.

Madubansi, M., Shackleton, C.M., 2007. Changes in fuelwood use and selection following electrification in the Bushbuckridge lowveld. S. Afr. J. Environ. Manage. 83, 416-426, http://dx.doi.org/10.1016/ j.jenvman.2006.03.014.

Matinga, M.N., 2010. We Grow Up With It: An Ethnographic Study of the Experiences Perceptions and Responses to the Health Impacts of Energy Acquisition and Use in Rural South Africa. University of Twente.

Matinga, M.N., Clancy, J.S., Annegarn, H.J., 2014. Explaining the nonimplementation of health-improving policies related to solid fuels use in South Africa. Energy Policy 68, 53-59, doi_http://dx.doi.org/10.1016/ j.enpol.2013.10.040

McCollum, D., Krey, V., Riahi, K., Kolp, P., Grubler, A., Makowski, M., Nakicenovic, N., 2013. Climate policies can help resolve energy security and air pollution challenges. Clim. Change 119, 479-494, http://dx.doi.org/10.1007/s10584013-0710-y.

Msimanga, B., Sebitosi, A.B., 2014. South Africa's non-policy driven options for renewable energy development. Renewable Energy 69, 420-427, http:// dx.doi.org/10.1016/j.renene.2014.03.041.

Murray, C.J.L., 1994. Quantifying the Burden of Disease: The Technical Basis for Disability-Adjusted Life Years. World Health Organ, Bull.

Naiker, Y., Diab, R.D., Zunckel, M., Hayes, E.T., 2012. Introduction of local Air Quality Management in South Africa: overview and challenges. Environ. Sci. Policy 17, 62-71, http://dx.doi.org/10.1016/j.envsci.2011.11.009.

National Planning Commission, 2013. National Development Plan. National Planning Commission, Pretoria, South Africa.

National Treasury, 2013. Carbon Tax Policy Paper. National Treasury, Pretoria, South Africa.

National Treasury, 2014. Carbon Offsets Paper. National Treasury, Pretoria, South Africa.

Norman, R., Cairncross, E., Witi, J., Bradshaw, D., 2007. Estimating the burden of disease attributable to urban outdoor air pollution in South Africa in 2000. S. Afr. Med. J. 97, 782-790.

OECD, 2012. OECD Environmental Outlook to 2050: The Consequences of Inaction. OECD, Paris.

Pegels, A., 2010. Renewable energy in South Africa: potentials, barriers and options for support. Energy Policy 38, 4945-4954, http://dx.doi.org/10.1016/ j.enpol.2010.03.077.

Purohit, P., Amann, M., Mathur, R., Gupta, I., Marwah, S., Verma, V., Bertok, I., Borken, J., Chambers, A., Cofala, J., Heyes, C., Hoglund, L., Klimont, Z., Rafaj, P., Sandler, R., Schöpp, W., Toth, G., Wagner, F., Winiwarter, W., 2010. GAINS Asia-Scenarios for Cost-Effective Control of Air Pollution and Greenhouse Gases in India. IIASA, Laxenburg, Austria.

Purohit, P., Munir, T., Rafaj, P., 2013. Scenario analysis of strategies to control air pollution in Pakistan. J. Integr. Environ. Sci. 10, 77-91, http://dx.doi.org/ 10.1080/1943815X. 2013.782877.

Rafaj, P., Schöpp, W., Russ, P., Heyes, C., Amann, M., 2013. Co-benefits of post2012 global climate mitigation policies. Mitig. Adapt. Strateg. Global Change 18, 801-824, http://dx.doi.org/10.1007/s11027-012-9390-6.

Rao, S., Pachauri, S., Dentener, F., Kinney, P., Klimont, Z., Riahi, K., Schoepp, W., 2013. Better air for better health: forging synergies in policies for energy access, climate change and air pollution. Global Environ. Change 23, 1122-1130, http://dx.doi.org/10.1016/j.gloenvcha.2013.05.003.

Reis, S., Grennfelt, P., Klimont, Z., Amann, M., ApSimon, H., Hettelingh, J.-P., Holland, M., LeGall, a.-C., Maas, R., Posch, M., Spranger, T., Sutton, M.a., Williams, M., 2012. From acid rain to climate change. Science (80-) 338, 1153-1154, http://dx.doi.org/10.1126/science.1226514. 
Ruiters, G., 2008. Free basic electricity in South Africa: a strategy for helping or containing the poor? In: McDonald, D.A. (Ed.), Electric Capitalism. HSRC Press, Cape Town, South Africa, pp. 248-263.

Scenario building Team, 2007. Long Term Mitigation Scenarios. Strategic Options for South Africa. Department of Environment Affairs and Tourism, Cape Town, South Africa.

Scorgie, Y., Annegarn, H., Burger, L., 2004. Study to Examine the Potential SocioEconomic Impact of Measures to Reduce Air Pollution from Combustion. Report to Fund For Research into Industrial Development Growth and Equity (FRIDGE) Trade and Industry Chamber, Johannesburg.

Shirinde, J., Wichmann, J., Voyi, K., 2014. Association between wheeze and selected air pollution sources in an air pollution priority area in South Africa: a cross-sectional study. Environ. Health 13, 32, http://dx.doi.org/ 10.1186/1476-069X-13-32.

South African Government, 2011. National Climate Change Response White Paper. South African Government, Pretoria, South Africa.

Spalding-Fecher, R., Matibe, D.K., 2003. Electricity and externalities in South Africa. Energy Policy 31, 721-734, http://dx.doi.org/10.1016/S03014215(02)00123-4.

Tait, L., Winkler, H., 2012. Estimating Greenhouse Gas Emissions Associated with Achieving Universal Access to Electricity in South Africa. Energy Research Centre, Cape Town, South Africa.

Thambiran, T., Diab, R.D., 2011a. Air pollution and climate change co-benefit opportunities in the road transportation sector in Durban. S. Afr. Atmos. Environ. 45, 2683-2689, http://dx.doi.org/10.1016/j.atmosenv.2011.02.059.
Thambiran, T., Diab, R.D., 2011b. The case for integrated air quality and climate change policies. Environ. Sci. Policy 14, 1008-1017, http://dx.doi.org/ 10.1016/j.envsci.2011.08.002.

The Presidency, 2014. Medium-Term Strategic Framework (MTSF) 2014-2019. The Presidency, Pretoria, South Africa.

UNFCCC, 2011. Compilation of information on nationally appropriate mitigation actions to be implemented by Parties not included in Annex I to the Convention. In: Ad Hoc Working Group on Long-term Cooperative Action under the Convention, United Nations, FCCC/AWGLCA/2011/INF.1.

Von Schneidemesser, E., Monks, P.S., 2013. Air quality and climate - synergies and trade-offs. Environ. Sci. Process. Impacts 15, 1315-1325, http:// dx.doi.org/10.1039/C3EM00178D.

Walwyn, D.R., Brent, A.C., 2015. Renewable energy gathers steam in South Africa. Renewable Sustainable Energy Rev. 41, 390-401, Available at: 〈http:// www.sciencedirect.com/science/article/pii/S1364032114007254〉 (accessed January 2, 2015)

Winkler, H., 2005. Renewable energy policy in South Africa: policy options for renewable electricity. Energy Policy 33, 27-38, http://dx.doi.org/10.1016/ S0301-4215(03)00195-2.

Winkler, H., Hughes, A., Haw, M., 2009. Technology learning for renewable energy: implications for South Africa's long-term mitigation scenarios. Energy Policy 37, 4987-4996, http://dx.doi.org/10.1016/ j.enpol.2009.06.062.

Winkler, H., Marquard, A., 2012. Methodologies for Carbon Budgets in South Africa. Energy Research Centre, Cape Town, South Africa. 